\title{
Enhance the Institution Reputation with Open Learning System-Based Distance Learning Development Prototype in Globalization Era
}

\author{
Adrian \\ IAIN Surakarta, Indonesia \\ adrian.rusman@gmail.com \\ Aminuddin \\ IAIN Surakarta, Indonesia \\ aminuddin@gmail.com
}

\author{
Fauzi Muharom \\ IAIN Surakarta, Indonesia \\ fauzi.muharom@gmail.com \\ Iga Setawarti \\ IAIN Surakarta, Indonesia \\ igasetawarti@gmail.com
}

\author{
Soleha \\ IAIN Surakarta, Indonesia \\ soleha.11@gmail.com
}

\begin{abstract}
Tardiness data input, an inability of the MIS to accommodate several curriculum changes fast are the basic problems the leadership has to notice. The approach applied in this research was research and development. Research and development were initially done by doing surveys and mapping on various supporting aspects/components such as the institution, the users, the establishment procedures/ developments through literature review, and the benchmarking in implementing distance learning. The obtained data were reduced and interpreted by using a SWOT analysis. The thing being developed was not the distance learning but the design or prototype of a distance learning-based magister program. The Conclusion this Research as Distance learning is highly possible to be implemented in IAIN Surakarta. The Open Learning System (OLS) based distance learning prototype at the magister program of IAIN Surakarta can be implemented in less than $50 \%$ of the total amount of the available subjects. The try out of the prototype is implemented by the acceptance of the rector and the senators written on the rectorate decree. The Open Learning System (OLS) based distance learning prototype in IAIN Surakarta is a dummy from the Digital Learning System which will be integrated with the SIAKAD system of IAIN Surakarta.
\end{abstract}

Keywords: open learning system, distance learning

\section{INTRODUCTION}

The advance of technology and information system revolutionizes the communication activities from communication which was affected much by the distance to borderless communication. Nowadays, technology is so varied and is involved in almost all aspects of life. Toffler in Muhadjirrefers to this third era as the information era. To make quality hi-tech work, quality data have to be assured first. It is not the data that adjust the system, but how the hi-tech system is used to make quality works.[1][2]

There are some groups of people who are in the high demand for information including institutional leadership. The leadership in doing the task and the other activities to manage the institutions and to make certain policies, of course, needs information support which is fast and accurate. This decision making is often done by using one single method or technique which eventually ends in a less accurate decision. Besides resulting in an accurate decision, doing an action quickly is also an essential factor for the success of an institution in achieving its vision and mission.

Education is the right for every people. Nowadays, educational institutions are many with their methods of learning. It ranges from conventional learning, which requires interaction in certain meetings in a classroom between the teacher and the learners; to learning that is borderless, not requiring a classroom. The latter is applicable by the use of technology which can be the means for the interaction between the teacher and the students regardless of the distance among them in cyberspace.

The status change of STAIN Surakarta to IAIN Surakarta demands continuous and consistent development in every aspect including information and technology development. Therefore, the development and application of information and technology needs to be conducted in IAIN Surakarta to improve the service quality for the people and to face the getting- 
more-competitive global challenge in terms of information and technology advancement. To provide fast, accurate, and effective information service; a good and quality information system is demanded, a system that always goes with the advancement of education and technology and technology that can provide effective and efficient service. With this quality information system, it is expected that IAIN Surakarta can progress along with the advancement of information and technology.

The status change of STAIN Surakarta to IAIN Surakarta demands continuous and consistent development in every aspect including information and technology development. Therefore, the development and application of information and technology needs to be conducted in IAIN Surakarta to improve the service quality for the people and to face the gettingmore-competitive global challenge in terms of information and technology advancement. To provide fast, accurate, and effective information service; a good and quality information system is demanded, a system that always goes with the advancement of education and technology and technology that can provide effective and efficient service. With this quality information system, it is expected that IAIN Surakarta can progress along with the advancement of information and technology.

The computer-based MIS implementation in IAIN Surakarta still demands further development in many aspects. Tardiness of the data input, the inability of the MIS in accommodating several curriculum changes fast are the basic problems the leadership has to notice. This problem also becomes an obstacle in the advancement of the institution itself in applying elearning and the other online-based learning models.

The information system developed by IAIN The information system developed by IAIN Surakarta requires some revisions as per to the development of the institution departments and the curriculum. The researcher agrees to what Jogiyanto[3][4] says that the information system development approach which follows the modern procedure, yet with inadequate types of equipment and techniques, is included as a classical approach. The information system developed by IAIN Surakarta is not yet adequate. The use of information systems in this globalization era is beneficial to support the study program not only as an information provider for managerial needs but also as a support online-based learning to distance learning.

The use of information systems in this globalization era is beneficial to support the study program not only as an information provider for managerial needs but also as a support online-based learning to distance learning. To improve the reputation of the institution in both national and international levels in terms of providing learning facilities and services online as well As giving technology-based learning. Therefore, this research is expected to design Open Learning System (OLS) based Distance Learning Development Model for Magister Program in IAIN Surakarta to Improve the Institution Reputation in the Globalization Era.

\section{A. Problem Formulation}

"How is the blueprint Open Learning System (OLS) based Distance Learning Development Model for Magister program in IAIN Surakarta to improve the institution reputation in this globalization era?"

\section{B. The Purpose of Development}

"To make the blueprint of Open Learning System (OLS) based Distance Learning Development Model for Magister program in IAIN Surakarta to improve the institution reputation in this globalization era?"

\section{The Benefits of the Research}

The benefits of the research are to:

a. Suggest the universities leadership in developing the Open Learning System based Magister program;

b. Be a consideration for the university leadership to be able to develop a Distance Learning Model applied in Magister program in IAIN Surakarta.

c. Support the institution in designing the Distance Learning Model blueprint in the Magister program in IAIN Surakarta as per the regulations in Indonesia.

\section{LITERATURE REVIEW}

\section{A. Distance Learning and E-Learning}

Distance learning is defined as an organized an educational process that bridges between the distance of the learners and the educator by the means of technology with minimum meetings. Distance learning is borderless, so the learners can get the flexibility of learning anywhere and any time, and they can access various references. It is usually conducted massively Distance learning revolutionizes from correspondence education to borderless e-learning as shown in the figure 1 . 


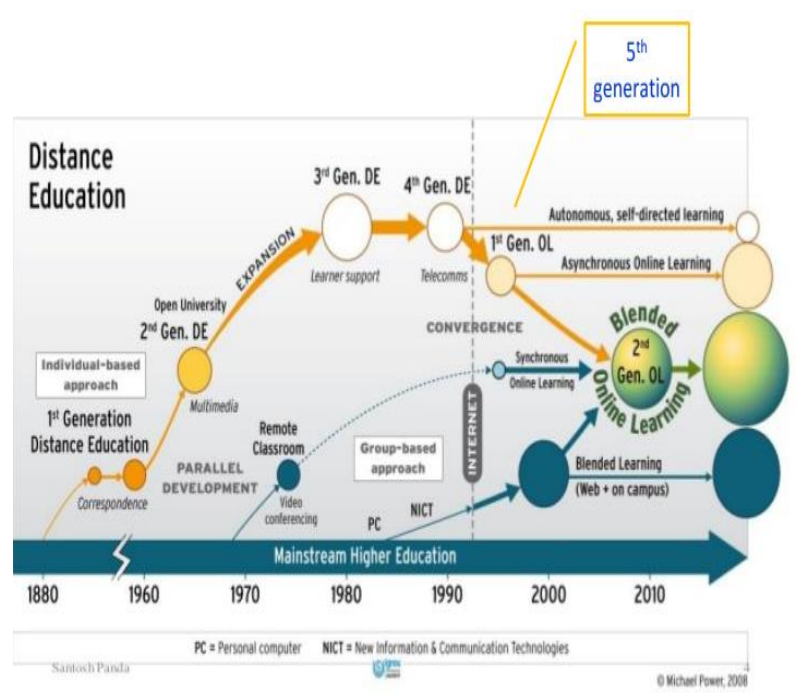

Figure 1 Distance Learning Evolution

Distance learning is a teaching and learningprocess conducted in a distance by the means of communication media [5].

Distance learning revolutionizes from correspondence education to the borderless elearning. E-Learning can be defined as an individual or group learning by using information and communication technology and network. This gives flexibility for the learners to study any time and anywhere and with anyone. It can also be combined with blended learning which can give some innovation in the teaching and learning process.

\section{B. Distance Learning Principles}

a. Open education; every individual has the chance to learn without any boundary[6]. Practically, everyone can enroll as an undergraduate anytime, freely choose the subject to learn, freely finish the education without bounded by time limit.

b. Distance learning; the learning is done in distance without any force to have a meeting in a classroom.

\section{The Evolution of Distance Learning}

The evolution of distance learning in Indonesia happens in several cycles as shown in the figure below:

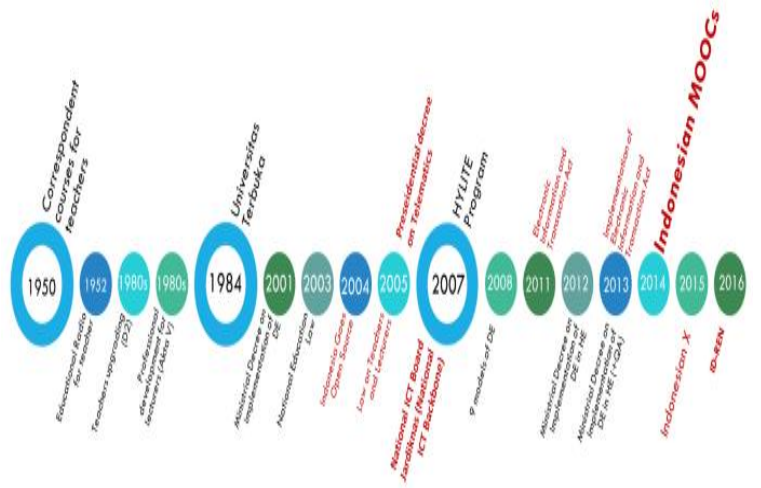

Figure 2 The Evolution of Distance Learning and eLearning in Indonesia (Source: Kemenristekdikti Ministry of Research, Technology \& Higher Education, 2016)

Ther are five models of distance learning in its development: 1. Correspondence Model; 2 Multimedia Model; 3. Telecommunication-based Learning Model; 4. ICT-based Learning (Hybrid); 5. E-Learning based Learning

\section{Pedagogy in Distance Learning and E-Learning}

The teaching and learning process in distance learning has a clear lesson plan. The pedagogical characteristics of distance learning and e-learning are as follows:

a. independent, guided, formal, residential, and/or structured learning; and using various learning sources; a) Learning is open; b) Learning is social; c) Learning is personal; d) Learning is augmented; e) Learning is multirepresented; f) Learning is mobile

b. using learning sources that are not always available in the same place as the learners;

c. applying the concept of learning in distance, the teacher and the learners are in different places;

d. emphasizing on independent, structured, and guided learning and using various learning sources;

e. emphasizing on CIT-based learning interaction although formal meeting is still possible to be conducted; 
f. using learning materials in the form of elearning and its combination with the other learning materials in various forms, formats, media, and other forms;

g. the learning sources are developed in various CIT-based forms;

h. $\quad$ using CIT-based learning media as learning media that can be accessed every day

\section{METHOD}

\section{A. Research Methodology}

As it is mentioned in the beginning, before coming to the development phase, this research was initiated by doing preliminary research on the university and its existing establishment mechanism. Thus, the approach applied in this research was research and development. Research and development were initially done by doing surveys and mapping on various supporting aspects/components such as the institution, the users, the establishment procedures/developments through literature review, and the benchmarking in implementing distance learning. The obtained data were reduced and interpreted by using SWOT analysis. The thing being developed was not the distance learning but the design or prototype of a distance learning-based magister program

\section{B. Development Procedures and Limitations}

The procedure of this research adopted the concept of distance learning development cycle that is similar to system life cycle consisting of five development phases: 1) analyze and plan the system and the prototype; 2) develop the program; 3) convert the previous system to the new system; 4) implement the program; 5) evaluate the implementation.

\section{Data Collection Instrument}

In collecting the data, research instruments were needed. The instruments were designed so that the researchers obtained the expected data related to OLSbased distance learning model development. The data were considered as secondary data since the primary data were already obtained from the university management information system. The primary data included in the management information system were institutional data that were considered reliable. The data used to develop the system are:

a) Primary Data-1: These data cover the main indicators of university development procedures such as distance learning-based department development procedures and skill development programs. If these types of data were not covered yet in the university management information system, it would be separately inputted.

b) Primary Data-2: Primary data-2 were supporting data that involved the preparation on university/faculty/major/department development such as undergraduates, lecturers, financial, employees, facilities and infrastructure data. Those data are usually found in the university management system so that the DSS can directly obtain the data online or offline.

c) Secondary Data: Secondary or supporting data obtained from several institutions or other elements were related to some consideration that might affect decision making. Those data were prospective undergraduates, employment distribution, community interest, and trends and the others.

\section{Data Validity}

Data validity was needed to get the expected result on the tryout phase and to achieve satisfying output when the product was implemented. The credibility of the data was tested by using : (a) reference test:this test was performed to measure the capability of several programming language types that would be used as a compiler in developing distance learning programs.; (b) triangulation: Triangulation was done by comparing various research sources[7]; and (c) expert judgment: Expert judgment through melaleuca focus group discussion/peer debriefing: The data were discussed to make sure that they were reliable through focus group discussion/peer debriefing

\section{E. Data Analysis Technique}

Data analysis technique used in this research was an interactivemodel analysis by Miles and Huberman[8]. The procedures in analyzing the data is illustrated in Figure 3.

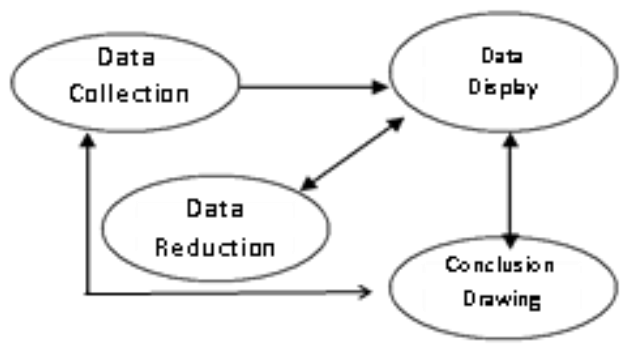

Figure 3. Interactive Models

a) Data collection; in this phase, every supporting data were conducting 
observation and library research on diverse distance learning rules and regulations.

b) Data reduction; the data in this phase could be functionally analyzed and grouped based on its function. The data were sorted into two groups: the data that supported the policies and the data that encouraged the learning model.

c) Data display; the reduced data were displayed in the form of narration, table, figure, and data flow diagram of the program prototype. Through the data display, the researchers were able to make a conclusion or undergo follow up action based on the suggestions.

d) The conclusion obtained from the data displayed at the beginning of the research was expected to find the content of the obtained data. Thus, finding the patterns, themes, similarities, and differences infrequent data were needed. The conclusion made based on the obtained data then would be displayed by the system in the form of output.

e) Conclusion drawing or verification: the conclusion was obtained from the suggestions recommended to the institution related to OLS-based distance learning model development

\section{F. Legalization Policy Analysis and Software Design}

\section{1) Real Condition of Policy in Iain Surakarta}

The quality of human resources and people's welfare can be improved. Quality human resources are reflected in the easiness of access quality education at every educational level by emphasizing the poor people, isolated people, and people on the borderland; as well as the improvement of the students' competence in mathematics, science, and literacy. The effort to realize the quality of democracy consolidation, security, and national stability is affected much by the success of socio-culture, education and religion development which is the responsibility of the Ministry of Religion. In RIP (Rencana Induk Pembangunan/ Principal Development Project) of IAIN Surakarta 2016-2035, it explains the roadmap of UIN Surakarta to realize the vision of 2035 as a World Class Islamic University.

The long term plan of IAIN Surakarta as shown on the figure is going to be implemented based on the roadmap which involves several phases as follows: 1) Forming phase, throughout the phase, the institution is focused on the strengthening of education, research, community service, facilities, and management. In this phase, the year 2019, IAIN Surakarta changes into UIN Surakarta; 2) Storming phase, the institution is led to be a Creannovative University throughout the year2021-2025. In this phase, UIN Surakarta emphasizes creative development and several innovative developments especially on academic research and publication, so the university can be responsive to the national development; 3) the Norming phase, the institution becomes a university in the year 2026-2030. In this phase, UIN Surakarta becomes a solid and independent university, both in the academic aspect and financial aspect; 4) Performing phase, throughout the year 2031-2035, the institution becomes Respected University.

In this phase, UIN Surakarta becomes a university with excellence in integrated science combined with the local wisdom, so the university can be acknowledged by the international as well as can be a role model on the other universities.

\section{2) Organization and Management System}

IAIN Surakarta develops an institutional system that is credible, accountable, responsible, independent, and just. This system runs effectively through an agreed mechanism that can manage and accommodate all of the elements, functions, and roles in every department. The system is supported by the Organizational culture and norm which is reflected by the implementation of the rule, leadership election system, lecturer ethics, student ethics, education staff ethics, reward and punishment system, and service guide and procedure (administration, library, laboratorium). The leadership election in IAIN Surakarta has shown credibility which is one of the principles of the system implemented by IAIN Surakarta. The chosen leadership is proven responsible. The system and its implementation in IAIN Surakarta are designed to meet the principles of credibility, transparency, accountability, responsibility, and justice.

3) Human Resources Condition and Readiness and the Infrastructure of Distance Learning

a) Human Resources

IAIN Surakarta human resources involve the lecturers and the staff. The lecturers are divided into PNS (civil servant) lecturers, no-PNS lecturers, honorary lecturers, and contract lecturers. Meanwhile, the staff is divided into PNS, honorary, and contract staff. There are the difference in selection system, placement, retention, and dismissal between the PNS and the non-PNS servant.

The selection system of the PNS lecturers is based on the guidance from the Ministry of Administrative and Bureaucratic Reform, National Civil Service Agency, and the Ministry 
of Religion. The selection process begins with the need for lecturer on every department, determining the formation, job vacancy announcement, administrative selection, announcement of the result of the administrative selection, organizing a test with CAT/CBT system, the announcement of the result of the test, interview, announcement on the interview result, filing, obtaining the decision letter from BKN which is followed with a letter of assignment, and letter of placement by the leadership.

Lecturers in IAIN Surakarta are 178 PNS lecturers and 79 non-PNS lecturers. These 253 lectures are divided into four faculties and 22 departments in IAIN Surakarta. The fulfillment ration is 6 lecturers per department. The lecturer student ratio is higher than the standard. This is based on the data which shows that the number of IAIN students is 11,101 and the lecturers are 257 , so the ratio is $1: 44$. It means that the ratio is higher than the standard 1:27-33. The mapping of the lecturers in IAIN Surakarta is as follows.

Table. 1 Lecturer Education Level at Surakarta IAIN

\begin{tabular}{|l|l|l|l|l|}
\hline No & $\begin{array}{c}\text { Tingkat } \\
\text { Pendidikan }\end{array}$ & $\begin{array}{c}\text { Dosen } \\
\text { PNS }\end{array}$ & $\begin{array}{c}\text { Dosen Tetap } \\
\text { Non PNS }\end{array}$ & Jumlah \\
\hline 1 & $\$ 3$ & 40 & 1 & 41 \\
\hline 2 & $\$ 2$ & 138 & 78 & 216 \\
\hline Jumlah & 178 & 79 & 257 \\
\hline
\end{tabular}

Based on this table, the number of doctorate lecturers are 41 of 257 lecturers (15.95\%). Meanwhile, the mapping of the lecturers' functional rank is as follows.

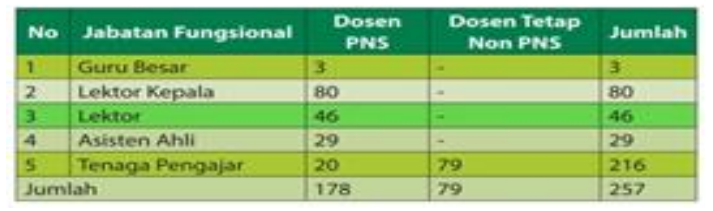

Based on this table, lecturers who are associate professors and professors are 83 of 257 lecturers $(32.30 \%)$. The lecturers recruited in the last three years are 43 , the retired lecturers are 2 , and the lecturers who passed away are 3. Therefore, there are addition lecturers who are 38 or $14.79 \%$ form the total number of the lecturers. The mapping of the educational staff is as follows.

Table. 3 Education Staff

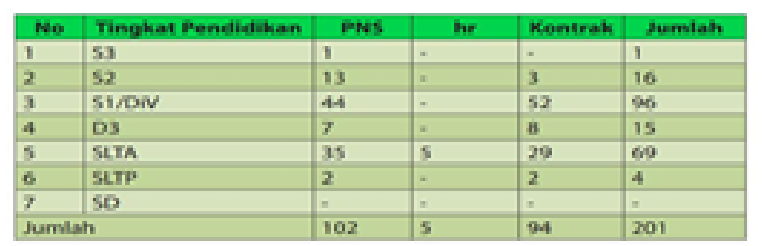

Based on the table, there are 113 graduated staff $(56.22 \%)$ from 201 staff in total. The ratio of the staff and the students is $201: 11,101$. So, the ratio is $1: 56$. On the other hand, the ration between the staff and the lecturers is $201: 257$ or 1:1.28. To know the satisfaction rate of the students towards the services given by the lecturers and staff satisfaction measurement system has been developed and conducted twice a year. This measurement is done after the students did the final examination on both the odd and even semesters. This measurement is conducted via soaked of IAIN Surakarta, as the requirement for the students to know the final scores.

b) The Current Academic and Teaching and Learning Process Condition

- Learning System

The system and learning quality control in IAIN Surakarta always refer to the curriculum to fulfill the institutional mandates. IAIN Surakarta has two mandates as an educational dan da'wah institution. the first mandate is as an educational, research, and community service institution based on research-based academic freedom and scientific principles. Meanwhile, the da'wah mandate is fulfilled to give a role on IAIN Surakarta as the agent of change. As an agent of change, IAIN Surakarta has to lead the social transformation based on constructive and truthful scientific principles. Different from the universities in general, IAIN Surakarta integrates the dimension of akhlak and professional dimensions. As a da'wah institution, IAIN Surakarta has to the role itself as the pillars of Islam (agent of Islamization), an institution that can spread the Islamic universal values in conducting education and providing community service. The role of da'wah which is in line with humanity and national principles. Islamic teaching has to be taught with critical openness, unexclusivity, and support for national development.

There are three achievement dimensions to fulfill those two mandates: religiosity, civility, and modernity. The first dimension, religiosity, reflects that IAIN Surakarta has to hold firmly on the religious principles, especially Islamic principles, both in the implementation of university tri dharma and in daily lives. The second is civility which means that all of the members of IAIN Surakarta have to refer to the values of adab. The third dimension is modernity meaning that the previous dimensions have to refer to the values of modernity so that IAIN Surakarta can be continuously relevant to the social change both quantitatively and qualitatively. 
These three dimensions are led to make IAIN Surakarta be able to: 1) role as an Islamic institution that can adjust to every society, 2) be inclusive, 3) integrate religious and cultural values, 4) provide entrepreneur skill, and 5) provide Arabic and English skills. Besides, IAIN Surakarta which located in the center of civilization in Central Java harmonizes Islamic and Javanese values. The relation between these two does not only need to be treated well but also how this relation has an academic and scientific basis. Therefore, Islam and Javanese culture are developed as the center of excellence. Historically, Islam and Javanese culture have many relations on the universal values and they also have significant roles in history as stated in the research conducted by the western people. Besides, the number of Muslims in Indonesia is the biggest in the world, and majorly they are in Java. Hence, Islamic and cultural values are important in the moderation development program which contributes to global peace. The global peace is impossible realized without peace among the religions, and that is why dialogue among them is needed. Therefore, Islam and Javanese culture role strategically not only on peace among the religions in Indonesia but also on the global level. Organizational unit in IAIN Surakarta who is responsible for the research and development on system and learning quality has been established, either in the level of faculty, post-graduate, or even on the institutional level. Faculty level organizational unit who is responsible for these activities involve department members, academic staff, laboratory staff, and library. Each department is led by a chairperson and their vices, academic staff is led by head of the academic division and head of administration, the laboratory staff is led by the head of the laboratory, and the library is led by library staff. Each unit is responsible for research and development of the teaching and learning on the corresponding faculty coordinated by the academic vice deen. In the post-graduate faculty, the one who has the responsibility is the post-graduate director and head of division. Meanwhile, in the institutional level, the one who bears the responsibility on the research and development of the system and the quality of teaching and learning involves LPM (Lembaga Penjaminan Mutu - Quality Control Agency), UPT (Unit Pelaksana Teknis.

Perpustakaan - Technical ImplementingAgency) of library, academic division, and academic subdivision. All of these units are coordinated by academic and institution development vice-chancellor. The teaching and learning in IAIN Surakarta is based on research as per the mandate and achievement dimensions. As a result, graduated students of IAIN Surakarta can have competence suitable for the demand of the stakeholders. Every lecturer has to always update the learning material based on the relevant newest research. To encourage the lecturers to always do research, LP2M (Lembaga Penelitian dan Pengabdian Masyarakat - Research and Community Service Department) of IAIN Surakarta always make research programs for the lecturers, both for national and international level research. To realize researchbased teaching and learning, the students are also given tasks to research the real phenomena. The students are asked to formulate problems occurring on the field, which then are studied and analyzed to obtain alternative solutions. To support the IT-based teaching and learning process, the facilities and infrastructure of IAIN Surakarta have been supported by hotspot, LCD, and online siakad. By the availability of online siakad, every party involved in the academic process can do the process everywhere and anytime.

\section{- Quality Control on Teaching and Learning Process}

Now, IAIN Surakarta applies a quality control system under the coordination of LPM. LPM IAIN Surakarta has formulated a quality control policy based on the result of the Academic Quality Control Workshop which is officially implemented on January $2^{\text {nd }}, 2014$. The statement of this policy is, "IAIN Surakarta as an excellent and independent Islamic Institution generates graduates who are professional, highly competitive, and noble in character."

The quality control system applied by IAIN Surakarta always refers to the quality control policy and quality control target. Based on the policy and target, the quality control system always relates all of the elements of teaching and learning, such as lecturers, students, facilities and infrastructure, and administration. In doing the monitoring and evaluation of the learning system, PM IAIN always conduct the Internal Quality Audit (AMI). LPM IAIN Surakarta has implemented teaching and learning procedures since January $5^{\text {th }}, 2014$.

\section{- Monitoring and Evaluation}

To control the implementation of the policy and strategy, monitoring and evaluation are needed. Generally, the evaluation can be both external and internal. Internally, evaluation is done in stages that begin with each department and end at the institution. Therefore, each unit has to develop an internal quality control system (SPI) to realize the conducive academic condition. Externally, the evaluation is done by the quality control agency in every academic unit in IAIN Surakarta. These agencies conduct external quality control for every academic unit. 


\section{Software Design Analysis}

Software designing and analysis are the first steps in realizing the planned concept. Several steps that must be done in this phase are as follows: - Need Analysis; - Functional Modeling; • Structural Modeling; • Behavior Modeling; • Interface Design.

\section{1) Need Analysis}

The first step in the analysis phase in need analysis. The need analysis is shown as a list which contains the capabilities of the system. The distance learning concept requires functional needs that represent the physical classroom in cyberspace as webbased learning media. The functional needs are as follows: - Placing the undergraduates based on the subjects they take on this final semester; - Dividing class based on the subjects; - Audiovisual communication among the undergraduates; • Cyberspace as learning media replacing the function of whiteboard. Besides the functional needs, there are also non-functional needs that have to be applied in the system to support the learning process in the system itself. The non-functional needs are as follows: - The system must be accessible from browser by using standard networking; - The system has to be compatible with several hardware like webcam, microphone, and speaker; - Class division has to be done automatically based on the data basis of the Academic Information System; - The use of Academic Information System can only access the corresponding subject.

\section{2) E-Learning Business System Management Development}

Generally, the e-learning system can be presented on the following figure (Breitner,2004):

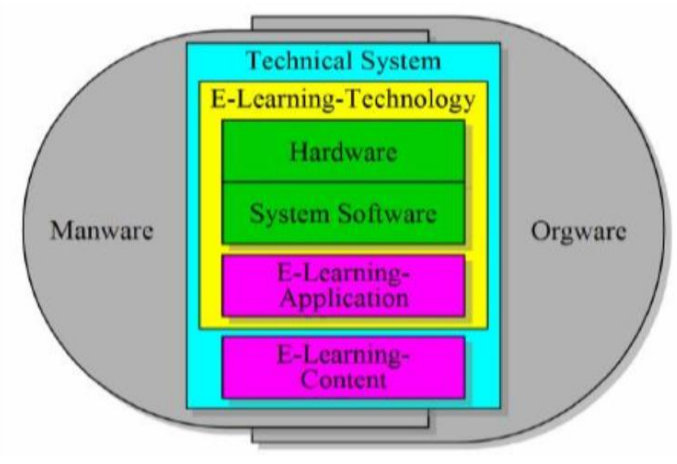

Figure 4. E-learning System Components

The e-learning technology domain involves hardware, software and e-learning applications that synergize one to the others creating an e-learning system. In other words, in designing an e-learning system, three aspects have to be considered: hardware (operation system, and the others), software, and applications (open source, premium, or indie application); since these three factors are the core of.

e-learning system. The technical system domain is an aspect of e-learning content development. The involvement of the creative team in serving the learning process is needed in displaying interesting and easy to understand content. The content development is designed to avoid the difference between distance learning and formal meetings. Appealing and attractive visualization is needed so that the undergraduates can be more interested and easy to access the e-learning. The main ware domain which relates to human involvement is needed to control the e-learning process in these cases is the CIT technicians. Domain Orgware as institutional aspect functions to manage the e-learning and the follow-up process of the e-learning.

\section{3) Functional Modeling}

The first step of modeling is functional modeling. This step displays each function available on the system used by the users.

\section{4) Structural Modeling}

After designing the functional system, the structure of the system itself needs to be designed. This structural modeling describes every component used to assemble the system structurally. Structural modeling is displayed on the class diagram illustrated in the figure below.

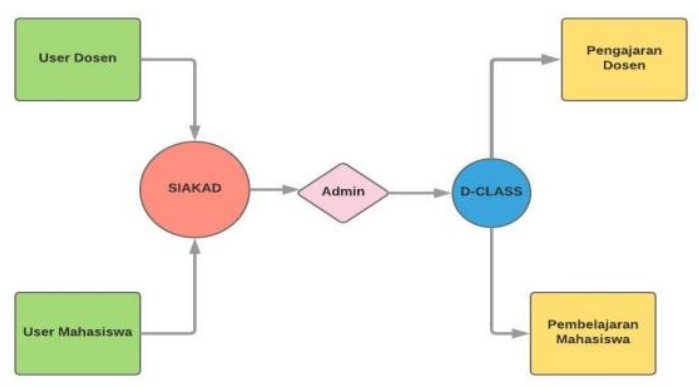

Figure 5. DFD-0 Distance learning class diagram

The class diagram displays each component that represents the relationships among the classes.

\section{5) System Behavior Modeling}

As the last phase of modeling, system behavior modeling describes the system from different points of view. This part clarifies how the system reacts to the users' actions. One of the system users is the lecturer. 


\section{6) Interface Designing}

One of the essential aspects that cannot be left behind is the user interface. The interface panel should be simple and user-friendly. Moreover, the resources used should be minimized so that the learning processes are effective and efficient. Certain components should be available on the interface so that they can be media used to assist the learning processes. The components are as follows: -Content page, Menu, Messaging system, Letterhead, and institutional tagline, Footer, External link An uncomplicated page displayed involves those components that are purposely

arranged based on its function. All the components are presented on a page. The position and the proportion are adjusted based on the importance of each part.

\section{7) Software Implementation}

After the analysis and planning are completed, the product being developed is implemented. In implementing the concepts, server is prepared first so that the distance learning becomes available to be accessed.

\section{8) Software Prototype Testing}

Before the system is launched, there is one last step called as software testing. Software is installed as it will be used in a real condition so that everything is carefully tested so that it runs well.

\section{a) Unit and Integration Testing}

Unit and integration testing is required to certify that every part of the software functions as it should be according to its structure before another testing is performed. academic information system, displayed announcement, open meeting database, and the list of classes are tested and compared so that the list of users, as well as lecturers, matches that of the academic information system.

\section{b) System Testing}

The testing process is also performed to check the system performance. The audiovisual of the conference and the users are tested to predict the real need of the network.

\section{CONCLUSION}

1) Distance learning is highly possible to be implemented in IAIN Surakarta.

2) The Open Learning System (OLS) based distance learning prototype at the magister program of IAIN Surakarta can be implemented in less than $50 \%$ of the total amount of the available subjects.

3) The try out of the prototype is implemented by the acceptance of the rector and the senators written on the rectorate decree.

4) The Open Learning System (OLS) based distance learning prototype in IAIN Surakarta is a dummy from the Digital Learning System which will be integrated with the SIAKAD system of IAIN Surakarta

The leadership of institutions with the acceptance of the senators can implement distance learning by using rectorate decree of IAIN Surakarta to implement distance learning with the percentage less than $50 \%$ of the total amount of the available subjects.

The leadership of an institution can budget for the procurement integrated digital learning facilities in SIAKAD. This research can be conducted further as stated in the follow-up research design in this research

\section{REFERENCES}

[1] Adrian. (2017), Metodologi Penelitian. Tulung Agung. Akademia Pustaka

[2] Muhadjir, M, Prof. Dr. H. (2007), Pokok Pikiran : Manajemen Pengembangan Program Studi Perguruan Tinggi berbasis Decision Support System, Yogyakarta.

[3] Hartono Jogiyanto, MBA, Ph.D. (2003)

Konsep Dasar Pemrograman Bahasa C, Yogyakarta: Andi Offset. http://code.google.com/p/openmeetings/wiki/

[4] Moekijat, (1991). Pengantar Sistem Informasi Manajemen. Bandung : CV Remadja Karya.

[5] Kemenristekdikti - Ministry of Research, Technology \& Higher Education, 2016

[6] CanedcomInternational (2002), Pengembangan Sekolah Efektif, : BukuPanduan untuk SLTP. Jakarta : Depdiknas.

[7] Davis,W, S. (1991). Sistem Pengolahan Informasi ( Information Processing System, Second Edition 1981) (diterjemahkan olehDrs. John B. Pasaribu). Jakarta. : Penerbit Erlangga.

[8] Dennis, Alan, System Analysis and Design with UML Version 2.0, WILEY, New Jersey, 2005). 